\title{
MODELO MATEMÁTICO PARA LA TRANSFRUCTOSILACIÓN DE ESTEVIÓSIDO CON $\beta$ - FRUCTOFURANOSIDASA INMOVILIZADA
}

\author{
MATHEMATICAL MODEL FOR TRANSFRUCTOSYLATION OF \\ STEVIOSIDE USING IMMOBILIZED $\beta$ - FRUCTOFURANOSIDASE
}

\author{
Fiorella Cárdenas T.
}

\author{
Departamento de Ingeniería Química, Universidad de Tohoku, Japón
}

\section{RESUMEN}

En el presente articulo, un modelo matemático fue diseñado para la transfructosilación de esteviósido con $\beta$-fructofuranosidasa inmovilizada considerando el equilibrio de partición entre la fase liquida y la fase de partícula, difusión y reacción dentro de la partícula. Las constantes cinéticas fueron estimadas mediante el ajuste de las ecuaciones cinéticas con los resultados experimentales de la síntesis de fructosil-esteviósido con enzima libre. Las otras constantes fueron estimadas mediante el ajuste del modelo matemático con resultados experimentales de coeficiente de equilibrio de partición, y síntesis de fructosil-esteviósido con enzima inmovilizada. El modelo describe la formación de fructosil-esteviósido en el tiempo para varias condiciones de concentración inicial de sustrato y enzima total en el sistema.

Palabras clave: transfructosilación, fructosil-esteviósido, análisis cinético, modelo matemático.

\section{ABSTRACT}

In the present article, a mathematical model for the $\beta$-immobilized fructofuranosidase was constructed considering the partition equilibrium between the liquid phase and the particle, diffusion and reaction within the particle. The kinetic constants were estimated by fitting the kinetic equations with the experimental data of the fructosyl-stevioside experiments using suspended enzyme. The other constants were estimated by fitting the mathematical model with experimental data of partition equilibrium coefficient, and fructosyl-stevioside synthesis using immobilized enzyme. The model could describe the fructosyl-stevioside formation under several conditions of initial concentration of substrate and total enzyme in the system.

Keywords: Transfructosilation, fructosyl - stevioside, kinetic analysis, mathematical model.

\section{INTRODUCCION}

Stevioside [1,2], the major sweet glycoside isolated from the leaves of Stevia rebaudiana Bertoni is commercially used as low calorie and non-cariogenic sweetener [3]. While this glycoside is about 140 times sweeter than sucrose at the concentration of $0.025 \%[4,5]$, it has slightly bitter taste and aftertaste. In order to alleviate these concerns, enzymatic saccharification of stevioside is known to be very effective [6-9]. Fructosyl-stevioside, transferred a fructosyl-residue to stevioside using $\beta$-fructofuranosidase from Arthrobacter sp. K-1 [10,11], was reported to have a high intensity of sweetness and to be obtained at high yield [12].

The expensive enzyme is often used in an immobilized form in industry for the purpose of repeated or continuous uses.
In this research, the transfructosylation of stevioside using suspended and immobilized $\beta$-fructofuranosidase in a buffer solution (pH 6.6) was performed experimentally. An appropriate support material for the immobilization of the enzyme was investigated. A mathematical model for this system was developed based on the reaction mechanism proposed in the suspended enzyme system [13]. The model constants were estimated by fitting the model with the experimental results for the partition equilibrium and the fructosylstevioside synthesis. In order to efficiently synthesize fructosyl-stevioside, the appropriate conditions were investigated experimentally and theoretically. 


\section{EXPERIMENTAL PROCEDURE}

\section{Suspended system}

Materials

Stevioside was used as a substrate and its purity was $55 \%$. Sucrose was used as another substrate and its purity was $99 \%$. $\beta$-fructofuranosidase from Anthrobacter sp. $\mathrm{K}-1$ was used as an enzyme. Fructose and glucose were used as a side products and its purity were $99 \%$.

\section{Fructosyl-stevioside experiment}

The experiment was started by adding $1 \mathrm{~cm}^{3}$ enzyme solution to $200 \mathrm{~cm}^{3}$ substrate solution $(\mathrm{pH}=6.6)$ in the flask. The flask was shaken in a water bath $\left(40^{\circ} \mathrm{C}\right)$ at a well-mixed condition. The experiments were also performed with addition of side-products (Fig. 1). The concentrations of substrates and products were analyzed by HPLC.

The initial substrates and enzyme concentrations were varied (Table 1). In this table; Ste, Suc, Fru, Glu are stevioside, sucrose, fructose and glucose, respectively, and $E$ is the enzyme.

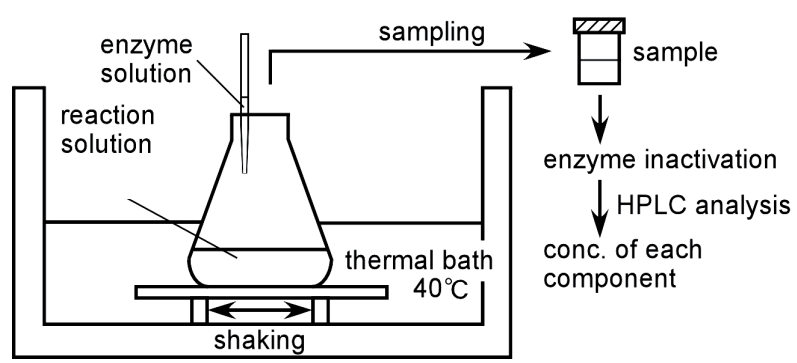

Figure 1. Schematic illustration of experimental apparatus in suspended enzyme system.

Table 1. Experimental conditions for transfructosylation of stevioside in suspended enzyme system.

\begin{tabular}{cccccc}
\hline $\begin{array}{c}\text { run } \\
\mathrm{N}^{0} .\end{array}$ & $\begin{array}{c}\mathrm{C}_{\text {Ste }, 0} \\
{\left[\mathrm{~mol} / \mathrm{m}^{3}\right]}\end{array}$ & $\begin{array}{c}\mathrm{C}_{\text {Suc }, 0} \\
{\left[\mathrm{~mol} / \mathrm{m}^{3}\right]}\end{array}$ & $\begin{array}{c}\mathrm{C}_{\mathrm{Glu}, 0} \\
{\left[\mathrm{~mol} / \mathrm{m}^{3}\right]}\end{array}$ & $\begin{array}{c}\mathrm{C}_{\mathrm{Fru}, 0} \\
{\left[\mathrm{~mol} / \mathrm{m}^{3}\right]}\end{array}$ & $\begin{array}{c}\mathrm{C}_{\mathrm{E}, 0} \\
{\left[\mathrm{units} / \mathrm{m}^{3}\right]}\end{array}$ \\
\hline $1-1$ & 0.5 & 20 & 0 & 0 & $2.0 \times 10^{5}$ \\
$1-2$ & 0.5 & 40 & 0 & 0 & $2.0 \times 10^{5}$ \\
$1-3$ & 1.0 & 20 & 0 & 0 & $2.0 \times 10^{5}$ \\
$1-4$ & 0.5 & 20 & 0 & 0 & $4.0 \times 10^{5}$ \\
$1-5$ & 0.5 & 20 & 40 & 0 & $2.0 \times 10^{5}$ \\
$1-6$ & 0.5 & 20 & 0 & 40 & $2.0 \times 10^{5}$ \\
\hline
\end{tabular}

\section{Immobilized system \\ Materials}

The substrates and enzyme used were the same as those in the suspended enzyme system. The strong base anion exchange resins, porous type; Diaion HPA25 (particle diameter of $250 \mu \mathrm{m}$ ) was selected for the immobilization of $\beta$-fructofuranosidase.

\section{Fructosyl-stevioside experiment}

The enzyme was immobilized in Diaion HPA25, by ionic binding (Fig. 2).

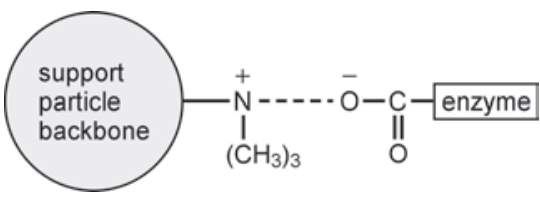

Figure 2. Schematic illustration of $\beta$-fructofuranosidase immobilized in the resin by the ionic binding

The experiment was started by adding $1 \mathrm{~g}$-wet immobilized enzyme particles to $200 \mathrm{~cm}^{3}$ substrate solution $(\mathrm{pH}=6.6)$. The flask was shaken in a water bath $\left(40^{\circ} \mathrm{C}\right)$ at a well-mixed condition. The initial substrate and enzyme concentration were regulated.

The experimental conditions are summarized in Table 2.

Table 2. Experimental conditions for transfructosylation of stevioside in immobilized enzyme system.

\begin{tabular}{ccccc}
\hline $\begin{array}{c}\text { run } \\
\text { N o. }\end{array}$ & $\begin{array}{c}\mathrm{C}_{\text {ste, }} \\
{\left[\mathrm{mol} / \mathrm{m}^{3}\right]}\end{array}$ & $\begin{array}{c}\mathrm{C}_{\text {suc, }} \\
{\left[\mathrm{mol} / \mathrm{m}^{3}\right]}\end{array}$ & $\begin{array}{c}\mathrm{W}_{\mathrm{p}} \\
{\left[\text { units } / \mathrm{m}^{3} \text {-particle] }\right.} \\
{[\mathrm{g}]}\end{array}$ \\
\hline $2-1$ & 0.5 & 20 & $312.4 \times 10^{6}$ & 1.0 \\
$2-2$ & 0.5 & 40 & $312.4 \times 10^{6}$ & 1.0 \\
$2-3$ & 1.0 & 20 & $312.4 \times 10^{6}$ & 1.0 \\
$2-4$ & 0.5 & 20 & $171.1 \times 10^{6}$ & 1.0 \\
\hline
\end{tabular}

\section{Partition Equilibrium Experiment}

The uptake amount of the substrates and products by the support particle was determined under the partition equilibrium condition. A weighed amount of the support particles without enzyme was immersed on $25 \mathrm{~cm}^{3}$ of the solution containing the substrate and products. This solution was well shaken (120 spm) in the water bath at $40{ }^{\circ} \mathrm{C}$ for 24 $h$. The initial concentrations of stevioside and saccharides (sucrose, glucose and fructose) in the solution were held constants at 0.5 $\mathrm{mol} \cdot \mathrm{m}^{-3}$ and $20 \mathrm{~mol} \cdot \mathrm{m}^{-3}$, respectively. The amount of support particles was varied in the range of $10-15 \mathrm{~g}$. 


\section{Mathematical model}

\section{Suspended system}

Three parallel reactions occurred in the system. The transfructosylation of stevioside (Ste) followed Ping- Pong Bi-Bi mechanism. Sucrose (Suc) hydrolysis, and fructosyl-stevioside (FSte) hydrolysis followed apparent ordered Uni $\mathrm{Bi}$ mechanism. [14]. The competitive inhibitions of fructose (Fru) and glucose (Glu) were also considered. The overall reaction mechanism is shown in Fig.3. Here, $k_{1}$ to $k_{12}$ denote the rate constants of each elementary reaction.

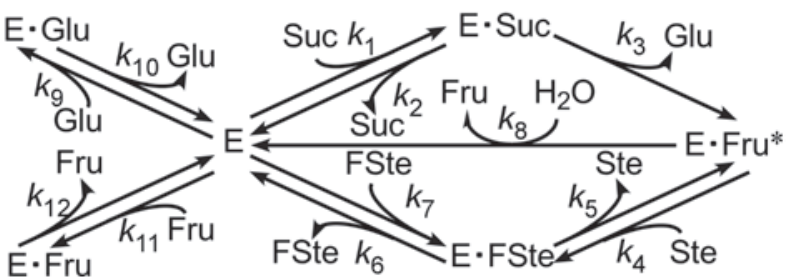

Figure 3. Schematic diagram of reaction mechanism

The reaction rates for each component $i$ are expressed in Eqs.(1)-(6).

$$
\begin{aligned}
& \overline{v_{\text {Ste }}}=\mathbf{V}_{\text {mh }}\left(-\mathbf{K}_{1} \overline{\mathbf{C}_{\text {Ste }} \mathbf{C}_{\text {Suc }}}+\mathbf{K}_{5} \overline{\mathbf{C}_{\mathrm{FSte}}}\right) / \bar{\sigma} \\
& \overline{v_{\text {F Ste }}}=\mathbf{V}_{\text {mh }}\left(K_{1} \overline{\mathrm{C}_{\text {Ste }} \mathrm{C}_{\text {Suc }}}-K_{5} \overline{\mathrm{C}_{\mathrm{FSte}}}\right) / \bar{\sigma} \\
& \overline{v_{\text {Suc }}}=\mathbf{V}_{\text {mh }}\left(-K_{1} \overline{\mathbf{C}_{\text {Ste }} \mathbf{C}_{\text {Suc }}}-\overline{\mathbf{C}_{\text {Suc }}}\right) / \bar{\sigma} \\
& \overline{v_{\text {Fru }}}=\mathbf{V}_{\mathrm{mh}}\left(\mathrm{K}_{5} \overline{\mathrm{C}_{\mathrm{FSte}}}-\overline{\mathrm{C}_{\mathrm{Suc}}}\right) / \bar{\sigma} \\
& \overline{v_{\text {Glu }}}=\mathbf{V}_{\text {mh }}\left(\mathrm{K}_{1} \overline{\mathrm{C}_{\text {Ste }} \mathbf{C}_{\text {Suc }}}+\overline{\mathbf{C}_{\text {Suc }}}\right) / \bar{\sigma} \\
& \bar{\sigma}=K_{\text {mh }}\left\{K_{1} K_{2} \overline{\mathbf{C}_{\text {Ste }} \mathbf{C}_{\text {Suc }}}\right. \\
& +\mathrm{K}_{1}\left(\overline{\mathrm{C}_{\text {Fru }}} / \mathrm{K}_{\mathrm{I}, \mathrm{Fru}}+\overline{\mathrm{C}_{\mathrm{Glu}}} / \mathrm{K}_{\mathrm{I}, \mathrm{Glu}}+1\right) \overline{\mathrm{C}_{\text {Ste }}} \\
& +\overline{\mathbf{C}_{\text {Suc }}} / \mathbf{K}_{\text {mh }}+\mathbf{K}_{\mathbf{3}} \overline{\mathbf{C}_{\text {F Ste }}}+\mathbf{K}_{\mathbf{4}} \overline{\mathbf{C}_{\text {Suc }} \mathbf{C}_{\text {Suc }}} \\
& \left.+\overline{\mathbf{C}_{\text {Fru }}} / \mathbf{K}_{\mathbf{I}, \mathbf{F r u}}+\overline{\mathbf{C}_{\mathbf{G l u}}} / \mathbf{K}_{\mathbf{I}, \mathrm{Glu}}+\mathbf{1}\right\}
\end{aligned}
$$

Immobilized system The following assumptions were considered: 1)enzyme is uniformly immobilized, 2)external mass transfer resistance is negligible, 3)there is a linear partition equilibrium of concentration $i$ between the liquid surface and the particle as Eq.(7), 4) intraparticle diffusion follows Fick's law, and the effective diffusitivities are described using a correlation in function of molecular weight as Eq.(8). The mass balance equations in the liquid phase are expressed in Eqs.(9)(12). Here, $\left\langle C_{i}\right\rangle$ and $\left\langle v_{i}\right\rangle$ are the volumetric average concentration and reaction rate of $i$ in the particle. The mass balance equations in the particle are expressed in Eqs. (13)-(16). The nine unknown kinetic constants $V_{m h}, K_{m h}$, $K_{\mathrm{l}, \text { Fru }}, K_{\mathrm{l}, \mathrm{Glu}}, K_{1}-K_{5}$ were estimated by fitting the experimental results in the suspended system. The partition coefficient, $H$, was determined from the partition equilibrium experiment. The regression coefficients for the effective diffusivity, $A$ and $B$, were estimated by fitting the results in the immobilized system.

$$
\begin{aligned}
& \left.\overline{C_{i}}\right|_{r=R_{\mathrm{p}}}=H_{i} C_{i} \quad \text { (7) } \quad D_{i}^{e f f}=A \times\left(M_{i}\right)^{-B}(8) \\
& \left.\frac{\mathrm{d} C_{i}}{\mathrm{~d} t}+\frac{1-\varepsilon}{\varepsilon} \frac{\left.\mathrm{d} \overline{C_{i}}\right\rangle}{\mathrm{d} t}=\frac{1-\varepsilon}{\varepsilon} \overline{\psi_{i}}\right\rangle \\
& \text { i.c. } t=0 ; C_{\mathrm{i}}=\left\{\begin{array}{c}
C_{\mathrm{i}, 0}(i=\text { Ste, Suc }) \\
0(i=\text { FSte, Fru, Glu })
\end{array}\right. \\
& \left.\overline{C_{i}}\right\rangle=3 R_{\mathrm{p}}^{-3} \int_{0}^{R_{\mathrm{p}}} \overline{C_{i}} r^{2} \mathrm{~d} r \\
& \left.\overline{Q_{i}}\right\rangle=3 \boldsymbol{R}_{\mathrm{p}}^{-3} \int_{0}^{R_{\mathrm{p}}} \overline{v_{i}} \boldsymbol{r}^{2} \mathrm{~d} \boldsymbol{r} \\
& \frac{\partial \overline{C_{i}}}{\partial t}=D_{i}^{e f f}\left(\frac{2}{\mathrm{r}} \frac{\partial \overline{C_{i}}}{\partial r}+\frac{\partial^{2} \overline{C_{i}}}{\partial r^{2}}\right)+\overline{v_{i}} \\
& \text { i.c. } t=0,0 \leq r \leq R_{\mathrm{p}} ; \overline{C_{i, 0}}=0 \\
& \text { b.c. } r=0 ; \frac{\partial \overline{\mathbf{C}_{i}}}{\partial r}=0{ }^{(15)} r=R_{\mathrm{p}} ; \overline{C_{i}}=H_{i} C_{i}
\end{aligned}
$$

\section{RESULTS AND DISCUSSIONS}

\section{Estimation of the kinetic constants}

The four kinetic constants for the sucrose hydrolysis, $\mathbf{V}_{\mathrm{mh}}, \mathbf{K}_{\mathrm{mh}}, \mathbf{K}_{\mathrm{l}, \mathrm{Glu}}, \mathbf{K}_{\mathrm{l}, \mathrm{Fru}}$, and the other kinetic constants, $\mathbf{K}_{1}-\mathbf{K}_{5}$ were estimated by fitting the kinetic model with the results obtained from the experiments for the sucrose hydrolysis and the fructosyl-stevioside synthesis, respectively. Here, $\mathbf{V}_{\mathrm{mh}}$ depends on the initial enzyme concentration, $\mathbf{C}_{E, 0}$, and hence, $\mathbf{V}_{\max }\left(=\mathbf{V}_{\mathrm{mh}} / \mathbf{C}_{E, 0}\right)$ was estimated instead of $\mathbf{V}_{\mathrm{mh}}$. The estimation procedure was similar to that described in the previous paper.

The experimental and fitted results by the model under 2 conditions are shown in Figure 4 by the symbols and the solid lines, respectively. In this figure, the symbols denote the experimental results and the lines denote the calculated values. The ordinates of the upper figure denote the concentrations of stevioside and fructosyl-stevioside, and those of the lower figure, denote the concentrations of sucrose, fructose and glucose. When the initial stevioside concentration increased from 0.5 $\mathrm{mol} \cdot \mathrm{m}^{-3}$ (Fig 4(a)) to $1.0 \mathrm{~mol} \cdot \mathrm{m}^{-3}$ (Fig. 4(b)), the maximum concentration of fructosyl-stevioside 
became higher. However, the depletion time of sucrose hardly changed. This is because the initial stevioside concentration was much lower $(1 / 40$ to $1 / 20)$ than that of sucrose.

The calculated lines were in good agreement with the experimental results under all conditions.

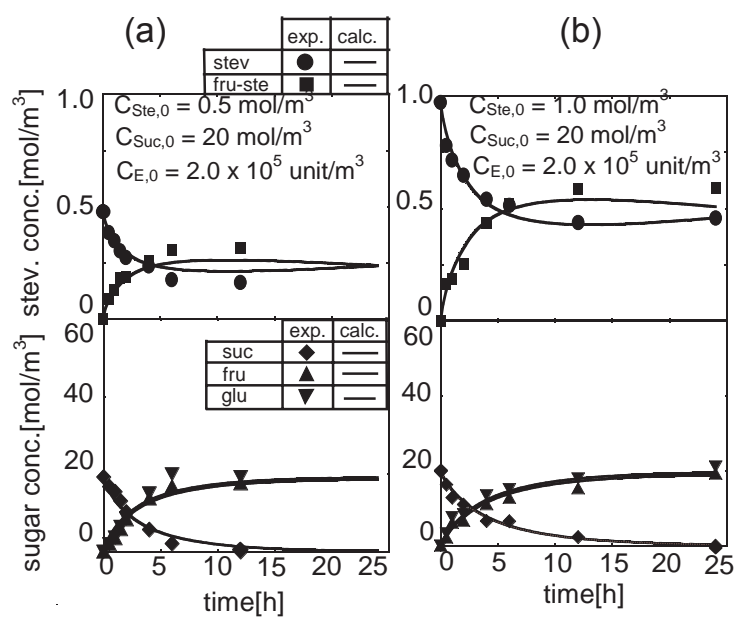

Figure 4. Experimental and calculated results for the transfructosylation of stevioside in suspended enzyme system

Therefore, the proposed reaction mechanisms were considered to be valid. The model equations could describe the fructosylstevioside synthesis under various conditions in suspended enzyme system. The estimated values of the kinetic constants which gave the minimum error between the experimental and calculated values are shown in Table 3. The estimated value of the Michaelis constant for the sucrose hydrolysis, $K_{\mathrm{mh}}$, of $8.75 \mathrm{~mol} \cdot \mathrm{m}^{-3}$ was close to the literature value of $9.1 \mathrm{~mol} \cdot \mathrm{m}^{-3}$ [12]. There were no literature values for the other constants.

Table 3. Estimated values of kinetic constants in suspended enzyme system.

\begin{tabular}{crl}
\hline constants & \multicolumn{2}{c}{ estimated values } \\
\hline $\mathbf{K}_{\mathbf{1}}$ & $5.41 \times 10^{-2}$ & {$\left[\mathrm{~m}^{3} \cdot \mathrm{mol}^{-1}\right]$} \\
$\mathbf{K}_{\mathbf{2}}$ & 6.74 & {$\left[\mathrm{~m}^{3} \cdot \mathrm{mol}^{-1}\right]$} \\
$\mathbf{K}_{\mathbf{3}}$ & 0.53 & {$\left[\mathrm{~m}^{3} \cdot \mathrm{mol}^{-1}\right]$} \\
$\mathbf{K}_{\mathbf{4}}$ & 14.0 & {$\left[\mathrm{~m}^{6} \cdot \mathrm{mol}^{-2}\right]$} \\
$\mathbf{K}_{\mathbf{5}}$ & 7.18 & {$[-]$} \\
$\mathbf{K}_{\mathbf{1}, \mathbf{F r u}}$ & 8.57 & {$\left[\mathrm{~mol} \cdot \mathrm{m}^{-3}\right]$} \\
$\mathbf{K}_{\mathbf{1}, \mathbf{G l u}}$ & 1.04 & {$\left[\mathrm{~mol} \cdot \mathrm{m}^{-3}\right]$} \\
$\mathbf{K}_{\text {mh }}$ & 8.75 & {$\left[\mathrm{~mol} \cdot \mathrm{m}^{-3}\right]$} \\
$\mathbf{V}_{\text {max }}$ & $1.71 \times 10^{-4}$ & {$\left[\mathrm{~mol} \cdot\right.$ units $\left.^{-1} \cdot \mathrm{s}^{-1}\right]$} \\
\hline
\end{tabular}

\section{Estimation of Partition Equilibrium Coefficients}

Figure 5 shows the results of partition equilibrium experiments for stevioside and saccharides. It shows a linear relationship between the concentration of stevioside and saccharides in liquid and particle phase. The partition equilibrium coefficient $H_{i}$ was estimated from the slope of these data using the least squares method and the calculated values are shown in Table 4.
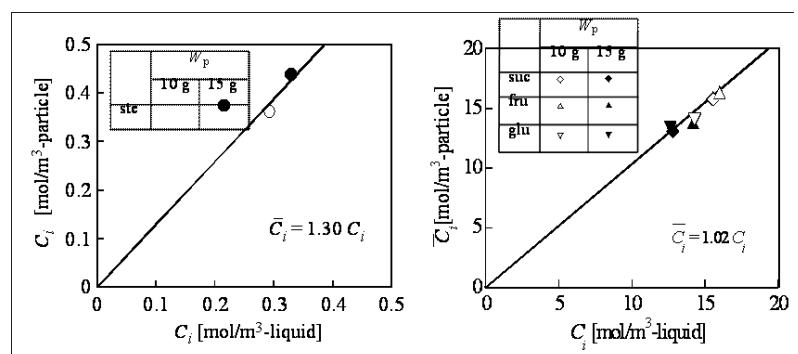

Figure 5. Equilibrium concentration of each component in support particle vs. those in liquid phase (a) stevioside, (b) saccharides (sucrose, fructose, glucose).

Table 4. Estimated values of partition coefficients.

\begin{tabular}{ccc}
\hline partition coefficients & \multicolumn{2}{c}{ estimated values } \\
\hline $\mathbf{H}_{\text {ste, }}\left(\mathbf{H}_{\mathrm{F} \text { ste }}\right)$ & 1.30 & {$\left[\mathrm{~m}^{3}\right.$-particle $\cdot \mathrm{m}^{-3}$-liquid] } \\
$\mathbf{H}_{\text {Suc, }}, \mathbf{H}_{\mathrm{Fru}}, \mathbf{H}_{\mathrm{Glu}}$, & 1.02 & {$\left[\mathrm{~m}^{3}\right.$-particle $\cdot \mathrm{m}^{-3}$-liquid] } \\
\hline
\end{tabular}

\section{Estimation of Effective Diffusion \\ Coefficients}

The regression coefficients for the effective diffusivity were estimated by fitting the mathematical model and the experimental results for the transfructosylation of stevioside using immobilized enzyme. For the kinetic constants and the partition coefficients, the estimated values listed in Tables were used. Using an arbitrary set of constants for $\boldsymbol{A}$ and $\boldsymbol{B}$, the dimensionless form of the mass balance equation in the support particle was numerically solved for the concentration of each component in the particle by CrankNicholson method. Next, the volumetric average concentration and the reaction rate in the support particle were calculated. The mass balance equations were numerically solved by the finite difference method to calculate the concentration in the liquid phase. The best fitted values of the constants were determined using the Simplex method [15] by minimizing the squared-sum of the relative errors between 
the calculated values in the liquid phase and the four sets of experimental data obtained under various conditions as shown in Table 4. For the numerical calculation, the time step was set at $0.1 \mathrm{~h}$, and the coordinate in the support particle, $\boldsymbol{r}$, was divided into 50 points. Figure 6 shows the fitted and experimental results for the transfructosylation of stevioside using immobilized enzyme. Under the control condition (Figure 6(a)), the experimental stevioside concentration decreased for 2 hour and then gradually increased. The change of the fructosyl-stevioside concentration was opposite to the stevioside concentration and the maximum value was obtained at $2 \mathrm{~h}$. The sucrose concentration decreased and reached almost zero after $4 \mathrm{~h}$. The concentrations of glucose and sucrose increased up to 4 hours and then asymptotically approached constant values. In the immobilization system, therefore, the transfructosylation of stevioside was found to occur similarly to the suspended system.

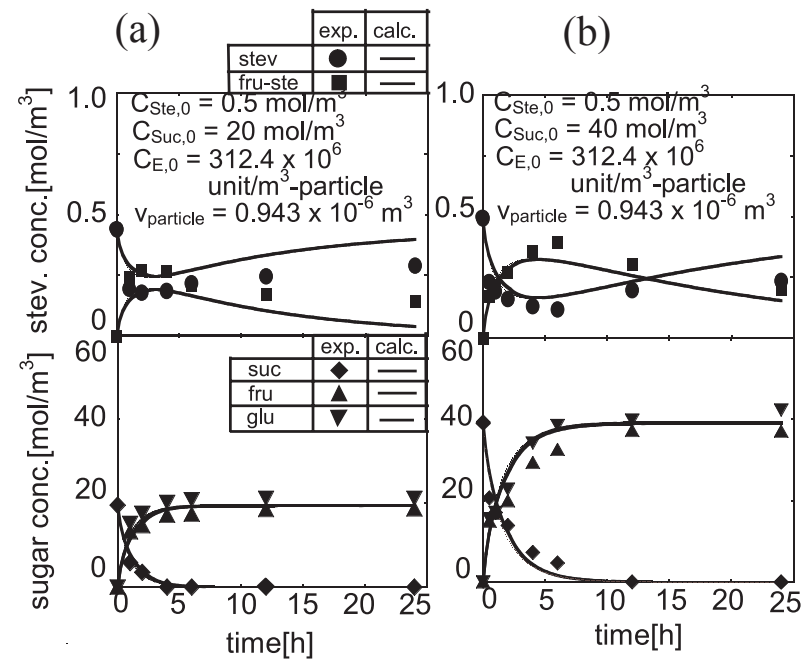

Figure 6. Experimental and calculated results for transfructosylation of steviode in immobilized enzyme system.

The fitted lines described the change of each component concentration and could predict the reaction time giving the maximum conversion of stevioside.

The estimated values of the regression coefficients for the effective diffusivities $\boldsymbol{A}$ and $\boldsymbol{B}$, are listed in Table 5.

Table 5. Estimated values of regression coefficients for effective diffusivity.

\begin{tabular}{clc}
\hline regression coefficients & \multicolumn{2}{c}{ Estimated values } \\
\hline$A$ & $1.06 \times 10^{-8}$ & {$\left[\mathrm{~m}^{2} \cdot \mathrm{s}^{-1}\right]$} \\
$B$ & 0.562 & {$[-]$} \\
\hline
\end{tabular}

The effective diffusivities of each component in the support particle were calculated with these values. The calculated values are shown in Table 6 compared with those from the empirical equations reported by Kimura and Nakao [16] in aqueous solution. For all compounds, the values in the support particle were slightly lower than those in aqueous solution, that indicates there is low intraparticle diffusion.

Table 6. Comparison of diffusivities in support particle and those in aqueous solution.

\begin{tabular}{lcc}
\hline \multirow{2}{*}{ diffusivities } & \multicolumn{2}{c}{ estimated values $\left[\mathrm{m}^{2} \cdot \mathrm{s}^{-1}\right]$} \\
\cline { 2 - 3 } & in support particle & in aqueous solution[ 16] \\
\hline$D_{\mathrm{Ste}}^{\text {eff }}$ & $2.47 \times 10^{-10}$ & $3.53 \times 10^{-10}$ \\
$D_{\mathrm{FSte}}^{\text {eff }}$ & $2.23 \times 10^{-10}$ & $3.23 \times 10^{-10}$ \\
$D_{\mathrm{Suc}}^{\text {eff }}$ & $3.99 \times 10^{-10}$ & $5.32 \times 10^{-10}$ \\
$D_{\mathrm{Fru}}^{\text {eff }}, D_{\mathrm{Glu}}^{\text {eff }}$ & $5.72 \times 10^{-10}$ & $7.24 \times 10^{-10}$ \\
\hline
\end{tabular}

\section{CONCLUSION}

The experiments of fructosyl-stevioside synthesis using suspended and immobilized $\beta$-fructofuranosidase in buffer solution were performed experimentally. A mathematical model for the system was constructed by considering considering the partition equilibrium between the liquid and support particle and the diffusion and the reaction in the particles. The kinetic constants were estimated by fitting the kinetic equations with the experimental results for the fructosyl-stevioside synthesis using the suspended enzyme. The other constants were estimated by fitting the mathematical model with the experiment result for partition equilibrium coefficient and the fructosyl-stevioside synthesis using immobilized enzyme. The model well described the synthesis behavior of fructosyl-stevioside under the various conditions of the initial substrate concentration and the total enzyme amount in the system. The model can predict not only the appropriate conditions to efficiently synthesize the fructosylstevioside, but also the reaction time giving the maximum conversion in the immobilized enzyme system.

\section{ACKNOWLEDGMENTS}

The author wish to thank Dr. Yonemoto, Dr. Kitakawa and Dr. Kubo from Department of Chemical Engineering, Tohoku University for their guidance during this research. 


\section{REFERENCES}

[1] Vis E, Fletcher HG Jr. Stevioside IV. Evidence that stevioside is a sophoroside. J Am Chem Soc. (1956)78:4709-4714.

[2] Mosettig E, Begliger U, Dolder F, Lichti H, Quitt P, Waters JA. The absolute configuration of steviol and isosteviol. $\mathrm{J}$ Am Chem Soc. 1963; 85:2305-2309.

[3] Kinghorn AD, Kaneda N, Baek NI, Kennelly EJ, Soejarto DD. Noncariogenic intense natural sweeteners. Med Res Rev. 1998; 18:347-361.

[4] Vasquez EV, Jakinovich W Jr. Stimulation of the Gerbil's gustatory receptors by some potently sweet terpenoids. J Agric Food Chem. 1993; 41:1305-1310.

[5] Schiffman SS, Booth BJ, Losee ML, Pecore SD, Warwick ZS. Bitterness of sweetness as a function of concentration Brain Res Bull. 1995; 36:505-513.

[6] Fukunaga Y, Miyata T, Nakayasu $\mathrm{N}$, Mizutani K, Kasai R. Enzymatic transglucosylation products of stevioside: separation and sweetness-evaluation. Agric Biol Chem. 1989; 53:1603-1607.

[7] Lovov SV, Kasai R, Ohtani K, Tanaka $\mathrm{O}$, Yamasaki K. Enzymic production of sweet stevioside derivatives:

transglucosylation by glucosidases. Agric Biol Chem. 1991; 55:2959-2965.

[8] Kitahata S, Ishikawa H, Miyata T, Tanaka O. Production of rubusoside derivatives by transgalactosylation of various $\beta$-galactosidase. Agric Biol Chem. 1989; 53:2923-2928.
[9] Kitahata S, Ishikawa H, Miyata T, Tanaka $\mathrm{O}$. Production of rubusoside derivatives by transgalactosylation of various $\alpha$-galactosidase. Agric Biol Chem. 1989; 53:2929-2934.

[10] Fujita K, Hara K, Hashimoto H, Kitahata $\mathrm{S}$. Purification and some properties of $\beta$-fructofuranosidase I from Arthrobacter sp. K-1. Agric Biol Chem. 1990; 54:913 919.

[11] Fujita K, Hara K, Hashimoto $H$, Kitahata S. Transfructosylation catalyzed by $\beta$-fructofuranosidase I from Arthrobacter sp. K-1. Agric Biol Chem. 1990; 54:2655-2661.

[12] Ishikawa H, Kitahata S, Ohtani K, Ikuhara C, Tanaka O. Production of stevioside and rubusoside derivatives by transfructosylationo $\beta$-fructofuranosidase. Agric Biol Chem. 1990; 54:3137-3143.

[13] Suzuki K, Fukumura T, Shibasaki Kitakawa N, Yonemoto T. Kinetic model for synthesis of fructosyl-stevioside using suspended $\beta$-fructofuranosidase.

Biochem Eng J. 2002; 10:207-215.

[14] Suzuki K. Kinetic study for the continuous production of fructosyl-stevioside. Master Thesis, Tohoku University, Japan. 2002.

[15] Nelder JA, Mead R. A simplex method for function minimization. Compt J. 1964; 7:308-313

[16] Kimura S, Nakao S. Design Methods for Membrane Separation Process. Tokyo: Kitami Shobo. 34 p.

E-mail: fiopa@hotmail.com 